\title{
ANALISIS GAYA GESEK DUA BENDA HOMOGEN SEBAGAI SUMBER ENERGI (STUDI KASUS: GESEKAN RODA KERETA LISTRIK DENGAN REL)
}

\author{
*Anggananda Berlian Rms ${ }^{1}$, Erfiana Wahyuningsih ${ }^{2}$ \\ ${ }^{1,2}$ Fakultas Teknik dan Informatika, Program Studi Teknik Mesin, Universitas Dian Nusantara, Jakarta, Indonesia
}

*Email Korespondensi:

anggananda.rms@undira.ac.id

\section{ARTIKEL INFORMASI}

Diterima:

3 March 2021

Direvisi:

15 April 2021

Dipublikasi:

16 Mei 2021

\begin{abstract}
ABSTRAK
Jumlah penumpang kereta api Jabodetabek (commuter line) pernah mencapai 1 juta orang per hari. Commuter line melayani 6 rute dengan 80 stasiun, padatnya jadwal kereta perlu diimbangi dengan performa kereta api salah satunya saat pengereman. Pengereman melibatkan benda berbahan logam; blok rem, roda dan lintasan (rel). Gesekan antara roda kereta dan rel saat pengereman menimbulkan energi panas. Energi yang timbul dari pengereman kereta berpeluang untuk diteliti lebih lanjut. Penulis menganalisa timbulnya energi panas sebagai energi yang terbuang saat pengereman. Proses analisa menggunakan model pengereman kereta api. Penggerak kereta api dimodelkan dengan motor Direct Current (DC), pejal baja sebagai blok rem, roda dan lintasan (rel). Sensor kecepatan terkopel dengan motor DC, hasil deteksi sensor sebagai nilai kecepatan kereta $(\mathrm{km} / \mathrm{jam})$. Pulsa luaran sensor kecepatan diinput ke kontroler Arduino Mega, bersamaan dengan massa pejal didapatkan nilai gaya gesek (Fk) pengereman. Perubahan suhu permukaan pejal mempengaruhi besar energi yang timbul saat gesekan. Suhu pejal awal (T0) dipengaruhi suhu ruangan dan suhu pejal setelah gesekan (T1), perubahan suhu dikonversi ke bentuk energi. Analisis hubungan Fk dengan energi, pengujian data pada tiga jenis pejal berbeda massa. Data kecepatan dan suhu tiap pejal dibandingkan satu sama lain. Jika gaya gesek bernilai 1,864 Newton maka nilai Energi yang dihasilkan yaitu 37,31 Joule.
\end{abstract}

Keyword: Arduino, Energi, Fk, Pengereman, Sensor

\section{PENDAHULUAN}

Moda transportasi darat Kereta Rel Listrik (KRL) Jabodetabek meningkatkan layanannya menjadi Commuter Line ditahun 2011. Badan Pusat Statistik menyebutkan tahun 2006 pengguna KRL Jabodetabek 8.774 orang dan 27,7 juta orang di tahun 2017. Bertambahnya penumpang menyebabkan beban gerbong meningkat, mengurangi laju kereta dan meningkatkan gaya gesek akibat pengereman. Pengereman pada KRL berkaitan dengan bagian berbahan logam: blok rem; roda; dan rel/lintasan kereta. Akibat gaya gesek saat pengereman (roda dan rem), menyebabkan terjadinya perubahan suhu. Percikan api kerap timbul akibat energi panas gesekan blok rem dengan roda KRL. Kualitas blok rem KRL juga mempengaruhi suara bising yang timbul saat pengereman. Suara bising sebagai polusi udara berpeluang mengganggu kesehatan pendengaran. 
Panas dan suara bising merupakan hasil energi akibat pengereman. Energi panas yang terbuang melalui pengereman berpeluang untuk diteliti dan dikembangkan. Penelitian dimodelkan dengan gesekan dua buah logam homogen. Sumber energi panas hasil gesekan dapat dimanfaatkan sebagai Energi Baru Terbarukan (EBT).

Pengereman kereta terbagi menjadi rem udara tekan dan rem udara tekan otomatis. Pengereman berkaitan dengan gaya gesek, panas yang ditimbulkan, dan kebisingan yang dihasilkan. Kebisingan yang ditimbulkan oleh kereta api saat melintas di atas rel meliputi suara mesin, klakson, dan gesekan antara roda dengan rel. Gesekan pada saat pengereman terjadi, menimbulkan perubahan energi kinetik menjadi panas1. Energi panas dari gesekan tersebut dapat dijadikan energi baru terbarukan. Motor Direct Current (DC) sebagai penggerak laju benda dapat diatur kecepatannya. Kecepatan motor DC diatur berdasarkan arah gerak putarnya Clock Wise (CW) dan Counter Clock Wise (CCW) atau besaran nilai kecepatannya.

Adapun identifikasi masalah pada penelitian ini adalah pengereman kereta rel listrik menimbulkan gaya gesek antara roda dan relnya. Gaya gesek antara roda dan rel yang terus menerus dapat menimbulkan energi. Energi didapat dari panas yang timbul saat roda dan rel bergesekan. Berdasarkan hal tersebut, maka dilakukan penelitian untuk membuktikannya dengan membuat pemodelan pengereman kereta. Model pengereman menggunakan pejal sebagai roda dan rel.

Tujuan dilakukannya penelitian ini adalah untuk melakukan analisis terhadap gaya gesek dua logam sejenis untuk memprediksi besar energi yang dihasilkan sehingga diperoleh korelasi koefisien gesek antar logam antara teori terhadap kondisi nyata (real) dan dapat digunakan untuk penelitian lebih lanjut sebagai Energi Baru Terbarukan (EBT).

\section{KAJIAN PUSTAKA}

Pengereman pada KRL berkaitan dengan bagian berbahan logam: blok rem; roda; dan rel/lintasan kereta. Akibat gaya gesek saat pengereman (roda dengan rem) dan (roda dengan rel), menyebabkan terjadinya perubahan suhu. Perubahan suhu dapat dikonversi menjadi sumber energi. Studi kasus ini memerlukan pustaka pendukung dalam pembuatan analisis gaya gesek sebagai sumber energi. Pemodelan menggunakan motor DC, sensor Rotary Encoder, Arduino Mega, dan lain-lain. Konfigurasi tiap perangkat dipelajari dan ditelusuri antara lain:

\section{Hubungan Kecepatan dengan Gaya Gesek}

Gaya gesek merupakan gaya yang berarah melawan gerak benda atau arah kecenderungan benda akan bergerak. Gaya gesek timbul apabila dua buah benda bersentuhan3. Gaya gesek antara dua buah benda padat misalnya gaya gesek statis dan kinetis. Gaya gesek kinetis atau dinamis (Fk) adalah gesekan yang terjadi ketika dua benda bergerak relatif satu sama lainnya dan saling bergesekan. Gaya gesek kinetis terjadi saat benda dalam keadaan bergerak.

Dimana :

$$
F k=\mu k \cdot N
$$

$F k=$ Gaya gesek kinetis maksimum (Kgf atau $\mathrm{N})$

$\mu k=$ Koefisien gesekan kinetis (tanpa satuan)

$$
\mathrm{N}=\text { Gaya normal }
$$

Roda kereta berputar dengan radius tertentu, terdapat salah satu gaya yang bekerja pada kereta berupa gaya sentrifugal. Berikut merupakan rumus yang menggambarkan gaya sentrifugal (linier) pada kereta

Selain gaya sentrifugal, roda kereta juga mengalami gaya akibat rotasi sebesar :

$$
F=\frac{m v^{2}}{R}
$$

Ditinjau gerak translasi pada bola yang bergerak pada lintasan lurus, dengan asumsi bahwa semua gaya luar bekerja di pusat massa bola maka hukum II Newton menjadi :

Dimana :

$$
\Sigma F x=m a, F-F k=m a, F-F k=I \alpha
$$

$\mathrm{F}=$ Gaya $(\mathrm{N})$ 


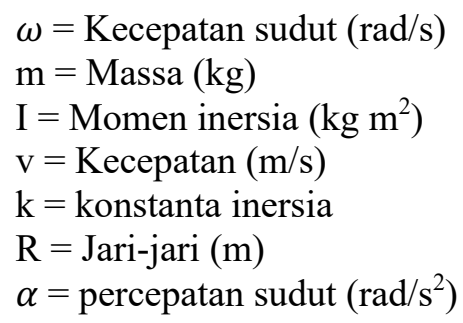

\section{Konduktifitas Termal dengan Energi}

Konduktivitas panas suatu bahan adalah ukuran kemampuan bahan untuk menghantarkan panas (termal), nilai konduktivitas termal suatu bahan menunjukkan laju perpindahan panas yang mengalir. Misalnya selembar pelat memiliki tampang lintang $\mathrm{A}$ dan tebal $\Delta \mathrm{x}$, kedua permukaannya dipertahankan pada suhu yang berbeda. Kemudian, dilakukan pengukuran panas Q yang mengalir tegak lurus terhadap permukaan selama waktu t.

$$
\frac{Q}{t}=k A \frac{T_{2}-T_{1}}{L}
$$

Dimana :

$\mathrm{Q}=$ Energi $(\mathrm{J})$

$\mathrm{k}=$ Konduktivitas termal $\left(\mathrm{W} / \mathrm{m}{ }^{\circ} \mathrm{C}\right)$

$\mathrm{t}=$ Waktu (s)

$\mathrm{T}=\operatorname{Suhu}\left({ }^{\circ} \mathrm{C}\right)$

$\mathrm{A}=$ Luas penampang lintang $(\mathrm{m} 2)$

$\mathrm{L}=$ Panjang $(\mathrm{m})$

\section{Sensor Rotary Encoder}

Rotary Encoder (Gambar 2.1) mendeteksi kecepatan motor. Pulsa yang dihasilkan merupakan representasi ruang gelap/hitam (high voltage) dan ruang terang/putih (low voltage). Pulsa tersebut diindikasi sebagai gerakan motor yang dideteksi melalui celah pada piringan modul sensor Rotary Encoder.

Keterangan Gambar :

$\mathrm{A}=$ celah gelap piringan Rotary Encoder

$\mathrm{B}=$ celah terang piringan Rotary Encoder

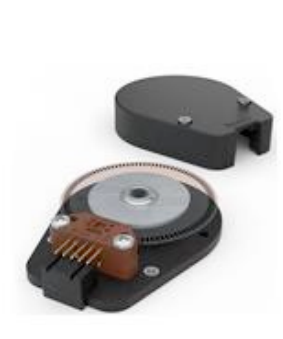

a)

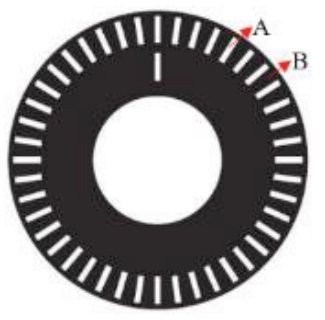

b)

Gambar 1. (a) Incremental Rotary Encoder, (b) piringan Rotary Encoder

Ketika benda berputar terhadap celah piringan Rotary Encoder menimbulkan efek cahaya gelap-terang secara bergantian sehingga menimbulkan pulsa digital sebagai keluaran sensor.

\section{Minimum Sistem}

Mikrokontroler Arduino Mega compatible dan fleksibel terhadap open source software Integrated Development Environment (IDE). Arduino Mega diprogram dengan software IDE, hasil pemrograman diupload ke memori mikrokontroler.

\section{Penampil Data}

LCD merupakan display dot matrix untuk menampilkan tulisan berupa angka atau huruf. Karakter huruf dan angka pada layar LCD mempermudah penyampaian informasi tertentu. 


\section{Sensor PIR (Passive Infrared)}

Sensor PIR (Passive Infrared) merupakan sensor yang berfungsi untuk mendeteksi suhu. Sesuai namanya, Passive Infrared, sensor ini bersifat pasif. Sensor ini menerima sinyal infrared yang dipancarkan oleh suatu objek (dalam hal ini pejal). Saat ini dipasaran banyak terdapat jenis sensor PIR.

Berikut ini adalah karakteristik dari sensor PIR:

1) Tegangan operasi $4.7-10$ Volt

2) Resolusi pengukuran yaitu $0,02^{\circ} \mathrm{C}$

3) Suhu yang dideteksi antara $-70-38^{\circ} \mathrm{C}$

4) Jangkauan deteksi 5 meter

5) Kecepatan deteksi 0.5 detik

\section{METODE}

Metodologi penelitian merupakan tahap-tahap penelitian yang harus ditetapkan dahulu sebelum melakukan pemecahan masalah, sehingga penelitian dapat dilakukan dengan terarah dan memudahkan dalam menganalisis permasalahan yang ada. Berikut diagram alir Metode Penelitian yang digunakan dapat dilihat pada gambar 2 berikut :

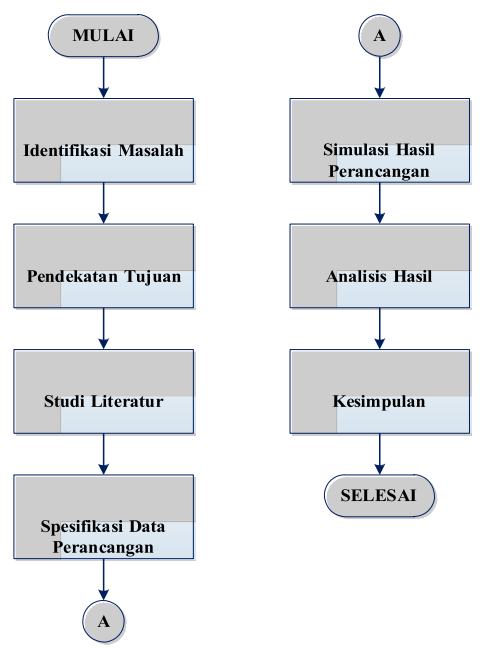

Gambar 2 Diagram alir proses penelitian.

\section{Prosedur Pengambilan Data}

Dalam penelitian ini gesekan roda kereta dengan rel didukung dengan model pengereman yang tepat. Motor 1 dimodelkan sebagai roda, nilai RPM lebih besar dari motor 2 sebagai rem. Ketelitian dan perencanaan yang matang penting pada proses perancangan model pengereman kereta. Komponen-komponen elektronika diintegrasikan dan instruksi program disisipkan ke kontroler sistem sesuai rancangan.

\section{Spesifikasi Data Dan Perhitungan}

Spesifikasi data yang digunakan adalah data kuantitatif dengan data diskrit. Data disajikan kedalam dua tabel; tabel pengujian sensor kecepatan dan tabel pengujian sensor suhu. Tabel pengujian sensor kecepatan dengan kolom; tegangan (v) input motor 1 dan 2 konstan, RPM motor 1, RPM motor 2, tachometer motor 1 (RPM), tachometer motor 2 (RPM), kecepatan motor 1 (v) m/s, kecepatan motor 2 (v) m/s dan gaya gesek (Fk). Tabel pengujian sensor suhu dengan kolom; RPM 1, RPM 2, waktu (s) pengereman konstan di berbagai nilai kecepatan, sensor suhu (T0 dan T1), suhu terdeteksi termometer (T0 dan $\mathrm{T} 1$ ), nilai error dan energi. Berikut ini merupakan gambar konstruksi dari pemodelan pengereman kereta (Gambar 3): 

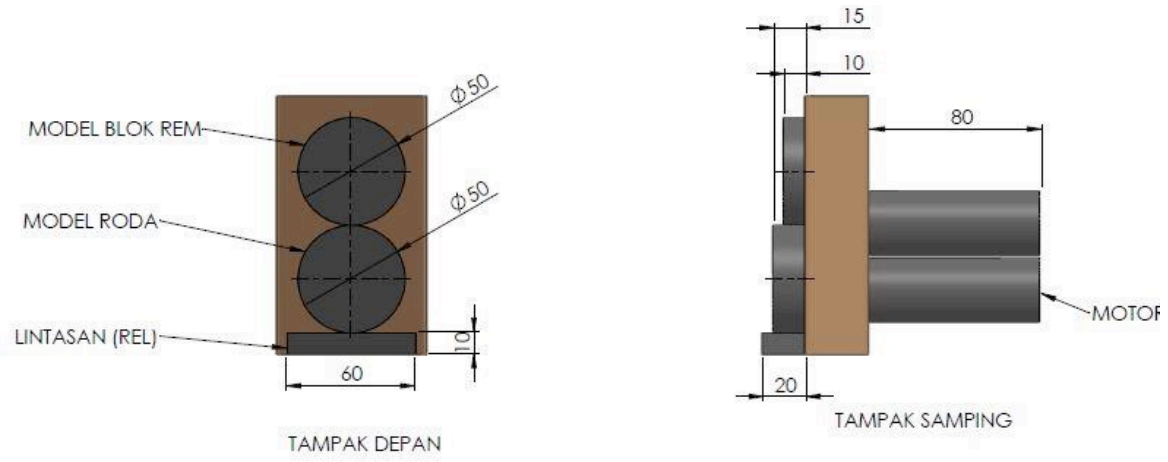

Gambar 3. Kontruksi Model Roda Kereta dengan Rel

\section{Hasil Pengujian Sensor Kecepatan}

Pengujian sensor kecepatan dilakukan ketika pemodelan pengereman kereta telah selesai dirancang. Data hasil pengujian output sensor rotary encoder (Tabel 1) sebagai berikut:

Tabel 1. Hasil Pegukuran Nilai Rpm

\begin{tabular}{|c|c|c|c|c|c|}
\hline \multirow{3}{*}{$\begin{array}{l}\text { Waktr } \\
0\end{array}$} & \multirow{3}{*}{$\begin{array}{c}\text { Tegmgngn Inpu: } \\
\mathrm{N}\end{array}$} & \multicolumn{2}{|c|}{ Clakfise(CW) } & \multicolumn{2}{|c|}{ Counter Clack Wise (CCW) } \\
\hline & & RPM Motor & RPM Motor & RPM Motor & RPM Motor \\
\hline & & 1 & 2 & 1 & 2 \\
\hline 0 & 0 & 0 & 0 & 0 & 0 \\
\hline$\Sigma$ & 3 & -5 & 40 & 75 & 40 \\
\hline 10 & 3 & -4 & 41 & 75 & 41 \\
\hline 15 & 6 & $15^{-}$ & 86 & $15:$ & 86 \\
\hline 20 & 6 & $15^{-}$ & 84 & $15^{-}$ & 85 \\
\hline 25 & 9 & 250 & 131 & 250 & 131 \\
\hline 30 & $\varrho$ & 249 & 133 & 250 & 133 \\
\hline 35 & 10 & 278 & 148 & 278 & 148 \\
\hline 40 & 10 & 27 & 146 & 27 & 146 \\
\hline 45 & 12 & 334 & 178 & 333 & 178 \\
\hline 50 & 12 & 334 & 17 & 334 & 178 \\
\hline 55 & 14 & 390 & 211 & 398 & 211 \\
\hline 60 & 14 & 399 & 211 & 399 & 211 \\
\hline
\end{tabular}


Tabel 2. Hasil Pengukuran Kecepatan

\begin{tabular}{|c|c|c|c|c|c|c|c|c|}
\hline No. & $\begin{array}{l}\text { Tegangan } \\
\text { Input (V) }\end{array}$ & $\begin{array}{c}\mathrm{M}_{1} \\
\text { (RPM) }\end{array}$ & $\begin{array}{c}\mathrm{M}_{2} \\
(\mathrm{RPM})\end{array}$ & $\begin{array}{c}\text { Tachometer } \\
1 \text { (RPM) }\end{array}$ & $\begin{array}{c}\text { Tachometer } \\
2 \text { (RPM) }\end{array}$ & $\begin{array}{c}\mathrm{vl} \\
(\mathrm{m} / \mathrm{s})\end{array}$ & $\begin{array}{c}\mathrm{V} 2 \\
(\mathrm{~m} / \mathrm{s})\end{array}$ & $\begin{array}{l}\text { Fk } \\
\text { (N) }\end{array}$ \\
\hline 1. & 3 & 75.1 & 40 & 74.8 & 39.7 & 0.197 & 0.105 & 0,168 \\
\hline 2. & 3 & 74.9 & 40 & 74.6 & 40.1 & 0.196 & 0.105 & 0,167 \\
\hline 3. & 6 & 167.1 & 86.1 & 167.2 & 86.2 & 0.437 & 0.225 & 0,845 \\
\hline 4. & 6 & 167.1 & 84.3 & 167.1 & 84.1 & 0.437 & 0.221 & 0,853 \\
\hline 5. & 9 & 250.3 & 131.3 & 250.1 & 130.9 & 0.655 & 0.344 & 1,879 \\
\hline 6. & 9 & 250.2 & 133.1 & 250 & 112.9 & 0.655 & 0.348 & 1,864 \\
\hline 3. & 10 & 277.7 & 148.1 & 278,1 & 148.2 & 0.727 & 0.388 & 2,294 \\
\hline 8. & 10 & 277.9 & 146.7 & 277,3 & 146.5 & 0.727 & 0.384 & 2,309 \\
\hline 9. & 12 & 334.2 & 178.3 & 333.9 & 177.9 & 0.874 & 0.467 & 3,321 \\
\hline 10. & 12 & 334.4 & 177.1 & 334.3 & 177.1 & 0.875 & 0.463 & 3,338 \\
\hline 11. & 14 & 398.8 & 210.6 & 398.7 & 210.2 & 1.044 & 0.551 & 4,755 \\
\hline 12. & 14 & 399.1 & 210.6 & 339 & 211 & 1.044 & 0.551 & 4,764 \\
\hline
\end{tabular}

Berikut ini penjelasan mengenai perhitungan untuk analisis nilai korelasi terdapat pada tabel berikut:

Tabel 3. Nilai Korelasi Koefisien Gesek

\begin{tabular}{cccccc}
\hline No & $\mathrm{x}$ & $\mathrm{y}$ & $\mathrm{x}^{2}$ & $\mathrm{y}^{2}$ & $\mathrm{xy}$ \\
& $\mathrm{vl}(\mathrm{m} / \mathrm{s})$ & $\mathrm{Fk}(\mathrm{N})$ & & & \\
\hline 1 & 0.197 & 0.048 & 0.039 & 0.002 & 0.009 \\
2 & 0.196 & 0.047 & 0.038 & 0.002 & 0.009 \\
3 & 0.437 & 0.249 & 0.191 & 0.062 & 0.109 \\
4 & 0.437 & 0.257 & 0.191 & 0.066 & 0.112 \\
5 & 0.655 & 0.542 & 0.429 & 0.294 & 0.355 \\
6 & 0.655 & 0.529 & 0.429 & 0.280 & 0.346 \\
7 & 0.727 & 0.648 & 0.528 & 0.420 & 0.471 \\
8 & 0.727 & 0.661 & 0.529 & 0.437 & 0.481 \\
9 & 0.874 & 0.938 & 0.765 & 0.881 & 0.821 \\
10 & 0.875 & 0.952 & 0.766 & 0.906 & 0.833 \\
11 & 1.044 & 1.361 & 1.089 & 1.852 & 1.420 \\
12 & 1.044 & 1.365 & 1.091 & 1.862 & 1.425 \\
\hline Jumlah & 7.868 & 7.597 & 6.084 & 7.064 & 6.392 \\
\hline
\end{tabular}

Hasil perhitungan tersebut menunjukkan bahwa adanya keterkaitan antara kecepatan dengan gaya gesek. $R 2=0,9541$ berarti kecepatan 95,41\% mempengaruhi gaya gesek.

\section{Hasil Pengujian Sensor Suhu}

Besarnya nilai suhu dipengaruhi kecepatan dan lamanya motor DC berputar. Kecepatan linear dipengaruhi besarnya RPM, keliling roda dan beban tambahan. Pejal besi dengan variasi massa, digunakan sebagai beban putaran motor. Suhu yang terdeteksi sensor PIR dibandingkan dengan alat ukur termometer.

Tabel 4. Hasil Pengukuran Suhu 


\begin{tabular}{|c|c|c|c|c|c|c|c|c|c|c|c|}
\hline \multirow[t]{2}{*}{ No. } & \multirow{2}{*}{$\begin{array}{c}\mathrm{M}_{1} \\
(\mathrm{RPM})\end{array}$} & \multirow{2}{*}{$\begin{array}{c}\mathrm{M}_{2} \\
(\mathrm{RPM})\end{array}$} & \multirow{2}{*}{$\begin{array}{c}\text { Waktu } \\
\text { (s) }\end{array}$} & \multicolumn{2}{|c|}{$\begin{array}{c}\text { Sensor Suhu } \\
\left({ }^{\circ} \mathrm{C}\right)\end{array}$} & \multicolumn{2}{|c|}{$\begin{array}{c}\text { Termometer } \\
\left({ }^{\circ} \mathrm{C}\right)\end{array}$} & \multicolumn{2}{|c|}{ Error (\%) } & $\Delta T$ & \multirow{2}{*}{$\begin{array}{l}\text { Energi } \\
\text { (Joule) }\end{array}$} \\
\hline & & & & $T_{0}$ & $\mathrm{~T}_{\mathrm{l}}$ & $\mathrm{T}_{0}$ & $\mathrm{~T}_{1}$ & $\mathrm{~T}_{0}$ & $\mathrm{~T}_{1}$ & $\left({ }^{\circ} \mathrm{C}\right)$ & \\
\hline 1 & 75.1 & 40 & 29,87 & 32.3 & 32.72 & 32.5 & 32.92 & $1 \%$ & $1 \%$ & 0.42 & 33.34 \\
\hline 2 & 74.9 & 40 & 29,87 & 32.3 & 32.73 & 32.5 & 32.93 & $1 \%$ & $1 \%$ & 0.43 & 34.14 \\
\hline 3 & 167.1 & 86.1 & 29,87 & 32.4 & 32.84 & 32.6 & 33.04 & $1 \%$ & $1 \%$ & 0.44 & 34.93 \\
\hline 4 & 167.1 & 84.3 & 29,87 & 32.5 & 32.95 & 32.8 & 33.25 & $1 \%$ & $1 \%$ & 0.45 & 35.73 \\
\hline 5 & 250.3 & 131.3 & 29,87 & 32.6 & 33.06 & 32.9 & 33.36 & $1 \%$ & $1 \%$ & 0.46 & 36.52 \\
\hline 6 & 250.2 & 133.1 & 29,87 & 32.6 & 33.07 & 32.9 & 33.37 & $1 \%$ & $1 \%$ & 0.47 & 37.31 \\
\hline 7 & 277.7 & 148.1 & 29,87 & 32.7 & 33.18 & 33 & 33.48 & $1 \%$ & $1 \%$ & 0.48 & 38.11 \\
\hline 8 & 277.9 & 146.7 & 29,87 & 32.9 & 33.39 & 33.3 & 33.79 & $1 \%$ & $1 \%$ & 0.49 & 38.90 \\
\hline 9 & 334.2 & 178.3 & 29,87 & 32.9 & 33.41 & 33.3 & 33.81 & $1 \%$ & $1 \%$ & 0.51 & 40.49 \\
\hline 10 & 334.4 & 177.1 & 29,87 & 33.1 & 33.62 & 33.5 & 34.02 & $1 \%$ & $1 \%$ & 0.52 & 41.28 \\
\hline 11 & 398.8 & 210.6 & 29,87 & 33.1 & 33.63 & 33.5 & 34.03 & $1 \%$ & $1 \%$ & 0.53 & 42.08 \\
\hline 12 & 399.1 & 210.6 & 29,87 & 33.2 & 33.74 & 33.7 & 34.24 & $1 \%$ & $1 \%$ & 0.54 & 42.87 \\
\hline
\end{tabular}

Tabel 5. Pengukuran Jarak Pengereman

\begin{tabular}{cc}
\hline Kecepatan Awal $\left(v_{0}\right) \mathrm{km} / \mathrm{jam}$ & Jarak Pengereman $(l)$ meter \\
\hline 60 & 249 \\
\hline 70 & 332 \\
\hline 80 & 420 \\
\hline 90 & 527 \\
\hline 100 & 650 \\
\hline
\end{tabular}

\section{HASIL DAN PEMBAHASAN}

\section{Analisis Data RPM Motor CW/CCW}

Berikut ini ialah grafik pengujian nilai RPM motor dengan arah yang berlawanan jarum jam (CCW) dan searah jarum jam $(\mathrm{CW})$ :

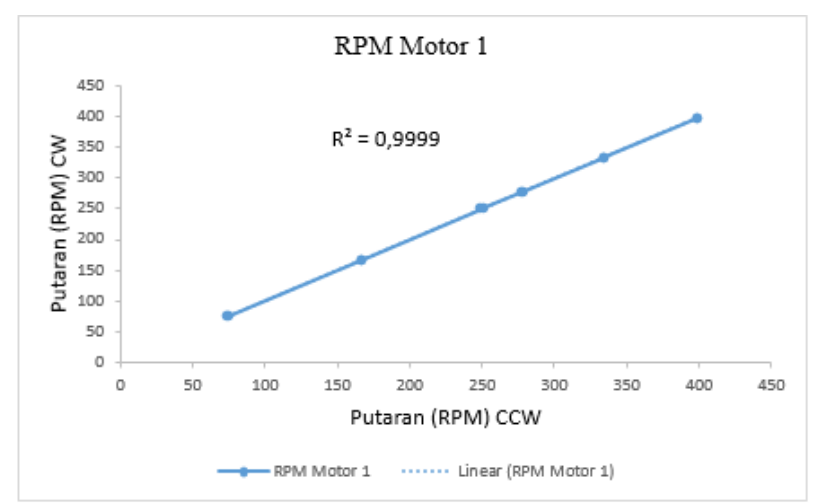

Gambar 4. Grafik nilai RPM motor 1 


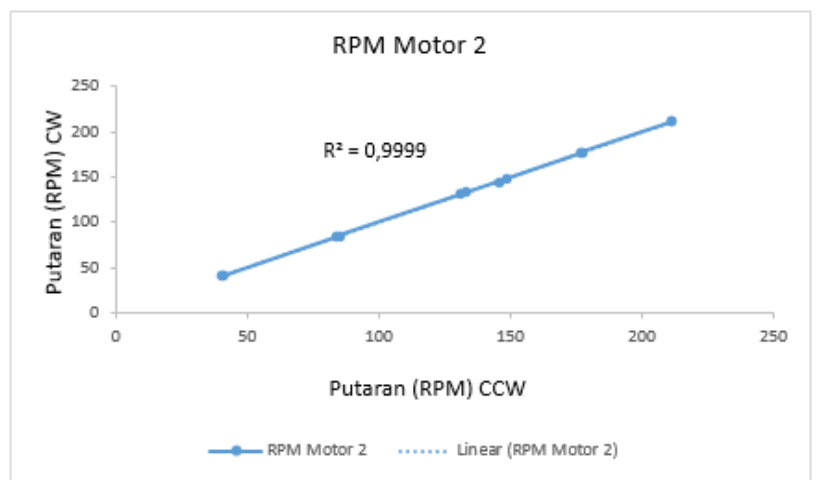

Gambar 5. Grafik nilai RPM motor 2

Berdasarkan grafik 4.1 dan grafik 4.2 diatas, dianalisis bahwa ketika motor 1 berputar dengan arah $\mathrm{CW}$ maupun CCW menghasilkan nilai RPM yang sama. Begitu juga dengan grafik nilai RPM motor 2. Hal ini dapat dibuktikan dengan metode korelasi. Jika hasil koefisien korelasi menunjukan nilai R2 yang berkisar antara $0,8<\mathrm{R} 2<1$ maka kedua variabel berhubungan erat (Ayyasy, ELINVO 2016, 5), nilai RPM arah CW sesuai dengan $\mathrm{CCW}$ dengan $\mathrm{R} 2=0.9$

\section{Analisis Data Gaya Gesek Terhadap Variasi Beban Massa}

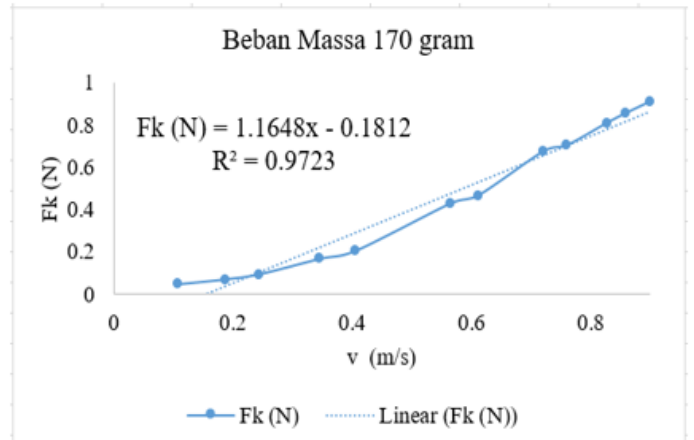

Gambar 6. Grafik Korelasi dari Gaya Gesek pada Beban 170 gr

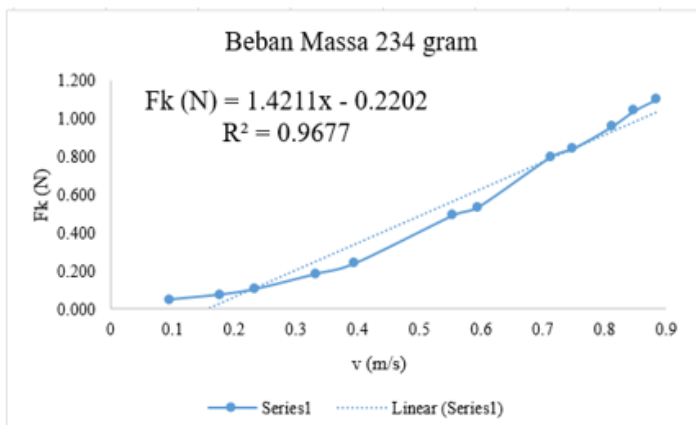

Gambar 7. Grafik Korelasi dari Gaya Gesek pada Beban 234 gr

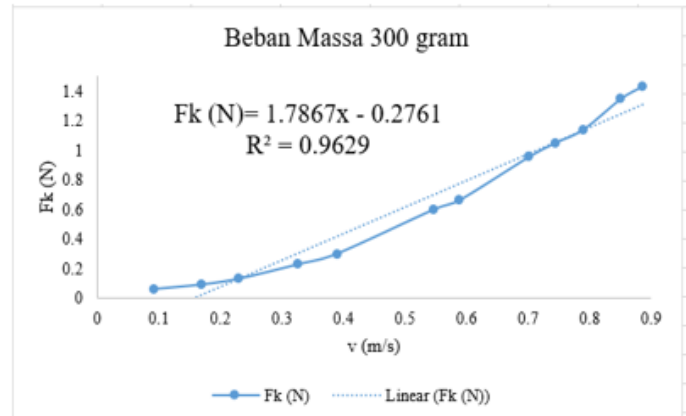

Gambar 8. Grafik Korelasi dari Gaya Gesek pada Beban 300 gr 
Perbedaan gaya gesek yang dipengaruhi oleh kecepatan dan beban massa terlihat pada hasil perhitungan korelasinya. Beban massa 170 gram memiliki persamaan $F k=1.1648 \mathrm{x}-0.1812$, Beban massa 234 gram memiliki persamaan $\mathrm{Fk}=1.4211 \mathrm{x}-0.2202$, Beban massa 300 gram memiliki persamaan $\mathrm{Fk}=1.7867 \mathrm{x}-0.2761$.

Keterangan:

$\mathrm{Fk}=$ Gaya Gesek $(\mathrm{N})$ dan

$\mathrm{x}=\mathrm{v}=$ Kecepatan Motor $(\mathrm{m} / \mathrm{s})$

Jadi, dalam keadaan kecepatan yang sama gaya gesek bernilai besar pada beban massa yg lebih berat. Nilai - nilai kolerasi R2 menunjukan bahwa diantara range $0,8<\mathrm{R} 2<1$, mengartikan bahwa ada keterkaitan antara kecepatan motor dengan gaya gesek. Kecepatan berbanding lurus dengan gaya gesek.

Setelah mendapatkan laju penyerapan kalor dari air dan dinding tungku induksi maka diperoleh total penyerapan kalor yang terjadi adalah $0,29 \mathrm{~kW}$.

\section{Analisis Data Hasil Sensor Suhu}

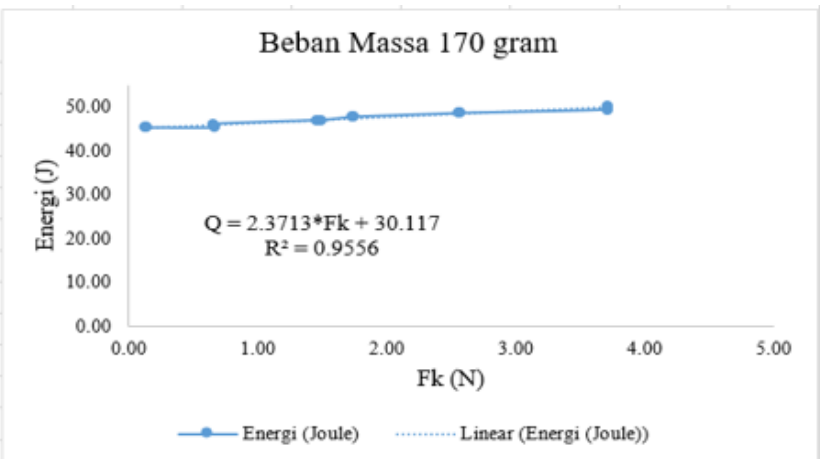

Gambar 9. Grafik Hubungan Gaya Gesek dengan Energi 1

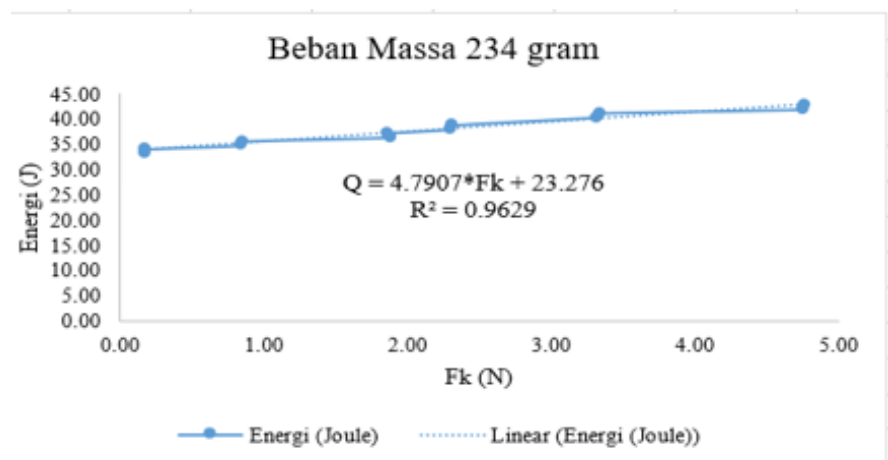

Gambar 10. Grafik Hubungan Gaya Gesek dengan Energi 2

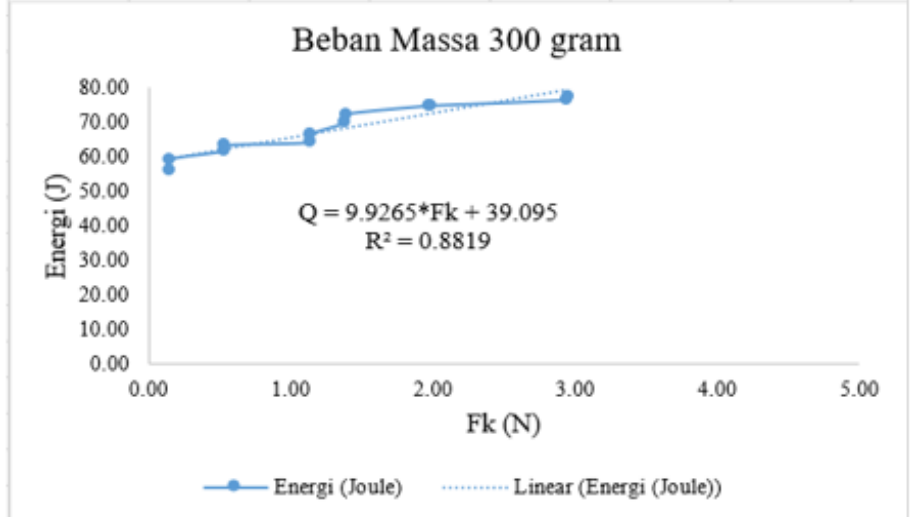

Gambar 11. Grafik Hubungan Gaya Gesek dengan Energi 3 
Besarnya Energi yang dipengaruhi oleh gaya gesek dan beban massa terlihat pada hasil perhitungan korelasinya. Beban massa 170 gram memiliki persamaan $\mathrm{Q}=2.3713^{*} \mathrm{Fk}+30.117$, Beban massa 234 gram memiliki persamaan $\mathrm{Q}=4.7907 * \mathrm{Fk}+23.276$, Beban massa 300 gram memiliki persamaan $\mathrm{Q}=9.9265 * \mathrm{Fk}+$ 39.095.

Keterangan:

$\mathrm{Q}=$ Energi $(\mathrm{J})$,

$\mathrm{x}=\mathrm{Fk}=$ Gaya Gesek $(\mathrm{N})$

Seperti terlihat pada grafik diatas, nilai korelasi pada Gambar 4.6. menunjukan bahwa hasil data linier karena R2 $=0.9556$. Nilai korelasi yang paling linier ada pada gambar 4.6. Perbedaan hasil korelasi ini dikarenakan variasi beban massa yang diberikan. Grafik-grafik tersebut membuktikan bahwa semakin besar nilai gaya gesek maka semakin besar pula energinya.

\section{KESIMPLAN DAN SARAN}

Kecepatan putar motor terdeteksi oleh sensor Rotary encoder dan telah teruji dengan pembanding alat ukur Tachometer. Putaran motor 1 dan motor 2 yang berlawanan arah menyebabkan gesekan. Gesekan antara lintasan dengan pejal yang terjadi terus menerus menimbulkan perubahan suhu. Perubahan suhu yang terdeteksi pada lintasan dapat dikonversi menjadi energi. Suhu pada lintasan dideteksi dengan infrared temperature dan thermometer digital sebagai pembanding. Dari hasil penelitian, maka dapat disimpulkan bahwa:

1) Nilai korelasi yang dihasilkan dari gaya gesek dan energi yaitu diantara $0,8<\mathrm{R} 2<1$, maka dapat dikatakan bahwa data yang dihasilkan merupakan linier. Hal ini sesuai dengan jurnal yang telah disebutkan sebelumnya, jika data pengujian linier maka gaya gesek mempunyai hubungan dengan energi.

2) Hasil penelitian ini membuktikan bahwa gaya gesek yang timbul dari pengereman kereta menghasilkan energi (Joule) yang dapat digunakan pada pemanfaatan energi selanjutnya.

3) Pejal yang dimodelkan sebagai beban yang ketika bebannya ditambahkan maka energi yang dihasilkan juga bertambah. Hal ini dapat dikorelasikan jika beban tersebut ialah penumpang, maka energi yang dihasilkan dari pertambahan penumpang/beban semakin besar.

4) Gaya gesek yang ditimbulkan juga dipengaruhi oleh kecepatan motor. Semakin bertambah kecepatannya maka semakin besar pula gaya geseknya.

5) Nilai korelasi dari data yaitu di antara $0,8<\mathrm{R} 2<1$. Jika hasil korelasi yang diperoleh kurang dari 0,8 atau lebih dari 1 , maka variabel - variabelnya tidak berhubungan erat.

\section{REFERENCES}

Astuti, Irnin Agustina Dwi. 2015. Penentuan Konduktivitas Termal Logam Tembaga, Kuningan dan Besi dengan Metode Gendongan. Prosiding Seminar Nasional Fisika dan Pendidikan Fisika (SNFPF) Ke-6 2015, ISSN: 2302-7827 Volume 6 Nomor 12015.

Ayyasy, Abdurrahman, dkk. 2016. Penggunaan Sensor LM35 Pada Kupluk Bayi Sebagai Pendeteksi Suhu dan Informasi Perubahannya Via SMS. PROSIDING SEMINAR NASIONAL ELINVO (Tema: Transformation of Electronics and Information in Daily Life: Challenges and Opportunities for Asean Economic Community).

Fitrianto, M. Bahar., Darmanto, Imam Syafa'at. 2015. Pengujian Koefisien Gesek Permukaan Plat Baja ST 37 pada Bidang Miring terhadap Viskositas Pelumas dan Kekasaran Permukaan. Momentum, Vol.11, No.1, April 2015, Hal. 13-18, ISSN: 0216-7395, e-ISSN 2406-9329.

Hartika, Ruri Zain. 2013. Sistem Keamanan Ruangan Menggunakan Sensor Passive Infra Red (PIR) Dilengkapi Kontrol Penerangan pada Ruangan Berbasis Mikrokontroler ATmega8535 dan Real Time Clock. Jurnal Teknologi Informasi \& Pendidikan, ISSN: 2086 - 4981 Vol. 6 No. 1, Hal 146-162.

Hidayati, Qory. 2012. Pengaturan Kecepatan Motor DC dengan Menggunakan Mikrokontroler Atmega 8535. Jurnal Poltekba 2012, Hal. 2.

Lutiyatmi dan Tri Daryanto. 2013. Karakteristik Produk Rem Blok Metalik untuk Kereta Api pada Industri Kecil Pengecoran Logam. Jurnal Foundry Vol. 3 No.2 Oktober 2013, ISSN: 2087-2259. 
N, Nalaprana dan Sri A. 2015. “Analisa Motor DC Sebagai Penggerak Mobil Listrik”. Jurnal Mikrokontroler, Robotika, Telekomunikasi dan Informasi, Tenaga Listrik (Mikrotiga). vol. 2, no.1, 28-34, ISSN: 2355 0457

Peryoga, Laksana Widya., Ir. Retnowati, M. T., Dr. Ir. Bambang Siswoyo M.T. 2014. Pengendalian Suhu Kelembaban Ruang Ekstraksi Metode Maserasi Minyak Atsiri Melati Kontroler PID berbasis Arduino Mega. Jurnal Penelitian Teknik Elektro Universitas Brawijaya.

Santoso, Amien., Eru Puspita dan Ressa Akbar. 2010. Argometer pada Ojek Motor Berbasis Mikrokontroler. Politeknik Elektronika Negeri Surabaya-ITS, Surabaya, Hal 2.

Sidehabi, Sitti Wetenriajeng., St Nurhayati Jabir. 2014. Pengontrolan Genset Jarak Jauh Melalui Website Berbasis Mikrokontroler Arduino Mega 2560-16AU. Seminar Nasional ke-9: Rekayasa Teknologi Industri dan Informasi Sekolah Tinggi Teknologi Nasional (STTNAS) Yogyakarta 249.

Valentino, Jean Mario. 2015. Analisa Resistance, Tractive Effort dan Gaya Sentrifugal pada Kereta Api Taksaka di Tikungan Karanggandul. Jurnal Puspitek Serpong. Volume 1 Nomor 1, April 2015. 